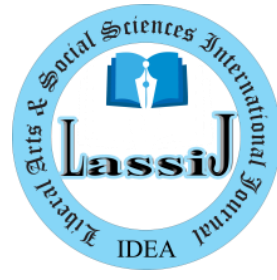

Research Article

ISSN: 2664-8148 (Online)

Liberal Arts and Social Sciences

International Journal (LASSIJ)

https: / / doi.org/10.47264/idea.lassij/3.2.2

Vol. 3, No. 2, (July-December) 2019, 11-19

https://www.ideapublishers.org/lassij

\title{
Indian Inclusion in CPEC: A Path to Indo-Pak Threat Reduction via Complex Interdependence
}

\author{
Sohail Ahmad ${ }^{1 *}$, Areeja Syed ${ }^{1}$ and Muhammad Makkey Bhutta ${ }^{2}$
}

1. Department of Humanities, International Relations Program, Comsats University Islamabad, Pakistan.

2. Department of Communication Studies, Bahauddin Zakariya University, Multan Pakistan.

Received: June 9, 2019

Published Online: January 21, 2020

\begin{abstract}
CPEC is a flagship project that can help India boost her economy to uplift the growing demands of infrastructural investment in the sector of energy, railroad connectivity and much more. As Pakistan and India get more economically integrated, the likelihood of any significant or minor war is going to be avoidable in the long run. India needs to understand that CPEC is not meant to destabilise any of the South Asian nations but to trigger the overall regional amalgamation. The addition of India to this global project is extremely industrious to take trilateral relations among China, Pakistan, and India towards new heights. With the backdrop of distrust, animosity, negative peace and zero political connectivity between India and Pakistan, CPEC is a feasible platform to eradicate these dilemmas if political connectivity is established. There is a need to have ideas and incentives which can convince India to be the part of CPEC. In addition, adverse reporting of media is also damaging this project by spreading false allegations. Therefore, the authors seek to explain how through CPEC, there can be less stress between India and Pakistan. What media can play its role to build the positive perception about this project. How media can make CPEC a vital source for reduction of hostility between the two states by applying the complex interdependence theory.
\end{abstract}

Keywords: CPEC, BRI, OBOR, Regional Integration, Interdependence, Peace Journalism

\section{Introduction}

India and Pakistan share the same cultural and historical bonding, yet they both are so far the least integrated nations. Even after sharing neighbourhood for the last 68 years as sovereign states, Pakistan and India however have a remotest supportive commitment with each other. Their liaison is noticeable for incessant hostility and animosity. Owing to the unsteady coexistence of both the states, India and Pakistan have remained involved in intermittent eruption of aggression which resulted in the wars of 1948, 1965, 1971, 1999 and mounting tensions at borders frequently (Rehman, Ashfaq, \& Khan, 2018). The fragmentary agenda of British legacy has made the peace process vulnerable. The dispute of Kashmir has been a real cause of disagreement and peril for peace in the South Asian region (Begum \& Ahmad, 2016). Other than Kashmir issue, numerous other issues keep fanning the flames of acrimony between India and Pakistan, but Kashmir issue remains the prime reason in inciting both states to get entangled into an unrelenting brawl. Kashmiris have been deprived of their basic right of the 
referendum from India since partition (Mohan, 2018). Both the state needs to have some sort of interdependence to mitigate this negative peace. The theory of complex Interdependence emphasizes the intricate ways in which the transnational actors become mutually dependent on each other's behaviours and sensitive to each other's needs because of increasing knots (Ranjan, 2015).

China-Pakistan Economic Corridor (CPEC) can be an entity for interdependence between India and Pakistan. CPEC is an ingenious collaborative endeavour between Pakistan and China. The project was initiated to fortify the regional stability and enhance the economic binding between both. CPEC is a network of roads, gas and oil pipelines, railways, and economic areas throughout Pakistan. Once completed, CPEC will join with Gwadar city in the Baluchistan and Pakistan with the Kashgar city in the Chinese region of Xinjiang. CPEC is a venture of regional connectivity and economic cooperation which is helpful for all the countries in the region. India is not part of CPEC since it refused to join it on account of a disputed terrain involving IndiaPakistan which is included in this project (Malik, 2017; Rehman, Hakim, Khan, \& Khan, 2018). India is in opposition due to Chinese control of Gwadar seaport because it grants China the clear-cut access to the Arabian Sea. This straightforward entrance through Gwadar facilitates China to be in control of the Indian Ocean smoothly as well as harm us strait which can concrete affect Indian authority in South Asia and its trading routes (Masood, 2018). Despite these thoughts, India needs to realize the benefits for herself to be in the CPEC.

\section{Literature Review}

\subsection{India-Pakistan: Perpetual Negative Peace}

India and Pakistan are considered to be on number one position as far as negative peace is concerned between them. The latest attack in Pulwama has added fuel to the fire and worsen the relations between India and Pakistan. A suicide bomber on $14^{\text {th }}$ February 2019 collided a car heaving with $300 \mathrm{~kg}$ of explosives into a procession of Central Reserve Police Forces (CRPF). The clash resulted in more than 44 Indian paramilitary personnel causalities, and at least 70 injured. The terror attack took place about $20 \mathrm{~km}$ from Srinagar in Pulwama, capital of Jammu and Kashmir territory. Soon after the attack, the Indian government Bhartiya Janata Party (BJP) declared war against Pakistan, blaming her for the army soldiers' causalities and swore vengeance and retribution. On the other hand, the tension escalated when Jaish-eMohammad (JeM), the whose stated mission is to "free Kashmir from India," took responsibility for the attack. Indian army breached the Line of Control (LOC) and tried to attack the alleged training centres of Jaish-e-Mohammad in Pakistan. Consequently, Pakistan hit back by doing surgical strikes (Islam, 2019). Two Indian planes were shot down, and an Indian pilot was arrested. Though, Pakistan released the Indian fighter pilot soon to deescalate the instant peril of further conflict with India which could distract to the nuclear-armed disagreement. Pakistani Prime Minister stated it a "peace gesture, whereas India asserted the stance that Pakistan was obliged to adhere to the law of "Geneva Convention."

Other than the sporadic armed clashes between India and Pakistan, both the states see negative peace between them even during the peace times. The term "negative peace" was coined by Johan Galtung which refers to a period devoid of war. The peace prevails on account of the absence of organized collective violence, but still, there is a deficit of trust between the states (Galtung, 1967). Whenever there is an attack in India, Pakistan is blamed for that and vice versa. Both the states are nuclear powers and have massive destructive nuclear weapons, and 
if any misadventure on either side prolongs, it might have a devastating effect in all the parts of South Asia (Idrees, Naazer, \& Rehman, 2017). Now the question is how both the states can cooperate with one another to alleviate the pressure and stress between them. Also, there is a dire need for both governments to act together to stop them from indulging in any armed conflict and replace negative peace with positive peace which means 'presence of cooperation.'

\subsection{Complex Interdependence Theory: An Approach to Mitigate the Tensions}

The term 'Interdependence' is used when two or more actors are dependent on each other for their personal gains. To make an ordinary person understand this term, let us take an example. Suppose a person who dines at a restaurant assuming himself independent by purchasing food independently. In fact, it is quite contrary since he is entirely dependent. He is sold that meal by a counterman. A restaurant manager must be supervising everything there. A chef cooked the food, and the raw food was bought by the restaurant from the cultivator who grew vegetables for food. This is a long chain, and all the links are dependent on each other for their personal interests. Similarly, the states are interdependent where all the state actors as well as non-state actors, are dependent upon one another by certain means (Hanna, Vaughn, \& Eisenstein, 2016).

Robert O. Keohane and Joseph S. Nye in the late 1970s developed the model of 'Complex Interdependence.' This model has defied the primary hypothesis of conventional and structural pragmatism, which always explained state behaviour through economic and military competence. Quite the reverse, complex Interdependence emphasized the involvement of cooperating actors in comparison with the state. The global organizations and institutions which could balance traditional military ability was the focal point. That the means of foreign policy in terms of trade and welfare matters too in comparison to the traditional security issues. Soon complex Interdependence turned out to be an essential element of the neoliberal standpoint and since it then has been extensively used in investigating the international politics and striving to recognize the eagerness of states to be a part of a supportive coalition with one another during mayhem and dependence (Rana, 2015).

Joseph Nye and Robert Keohane (1987) defined dependence as "a state of being determined or significantly affected by external forces." In most straightforward words, Interdependence can be defined, as reciprocal dependence. In international politics, interdependence refers to situations regarded as by reciprocal effects among countries or among actors in different countries (Keohane \& Nye, 1987). Being in the state of 'Interdependence' the countries collaborate due to their personal interest. Such collaboration results in is affluence and steadiness in the international structure. According to the trans nationalists/neoliberals "states are not motivated solely by national interest defined in terms of power'. neoliberals' contention is quite the opposite of the realists, who believe that it is unfair to divide international politics simply into' high' and 'low' politics. Even though the high politics of national safety and armed forces cannot be overruled, the low politics of economic, social and environmental issues are equally important for the international community (Rana, 2015).

Complex interdependence does not say that there will always be equal interdependence between states because most of the time, interdependence is Asymmetric, not symmetric (Afridi \& Khalid, 2016). If we talk about CPEC, India and Pakistan both are getting benefits from this project, but still, China is on the upper hand as a most significant beneficiary, so this project is also asymmetric in nature. According to Keohane \& Nye (1987), in a correlation with 
asymmetric interdependence between the actors, the actor who is less dependent on the other have more bargaining power than the one who is more dependent on the other (Walker, 2013). So obviously China who started this project has more advantage, but we must keep in mind that it will by and large benefit the whole region, particularly Pakistan and India (see, Khatoon, Rahim, Ali, 2018).

\section{Methods and Materials}

The nature of this study is qualitative, theoretical, and analytical in nature. This study involves two main sources of data collection. One source of data collection is through primary means and other is through the secondary sources. Primary data is first-hand knowledge and information collected by the researcher himself for a research reason. For this purpose, the researcher can employ various means to collect information like observation, interview, official statements, and government policies etc. The primary source is an imperative and valuable source to conduct and analyse the research. Secondary source for data collection is secondhand information or indirect knowledge since someone else has already collected the information, for a different purpose and the information has been stored on recorded for use by other researchers. The researcher will re-analyse this second-hand data for a new and different purpose. For this present research, data is collected from both primary and secondary sources. Primary source takes account of official newspapers and official websites of the government institutions, official statements, and government policies etc. Theoretical framework and historical background of this research are taken from the secondary resources. Different secondary resources e.g., documents, HEC recognized journals, international journals, books, websites are consulted for the analysis of the India's inclusion in CPEC project and its effects on the relationship of India and Pakistan.

\section{Discussion and Findings}

\subsection{CPEC and Benefits for India}

To fully understand the Indian perception of the Belt and Road Initiative (BRI), one needs to analyse them within the broader context of India-China relations. Administering relations with China is one of the hardest challenges for Indian politicians, like most other Asian countries. Presently, a huge unevenness between the two economies exists. Consequently, the 'Chinese are somehow relaxed about the rise of India' but 'the Indians are much more nervous about the rise of China' (Grant, 2010). China enjoys steady relations with plenty of India's South Asian neighbours, particularly with Pakistan. As compared to India, China is far more triumphant in its natural resource diplomacy on account of its centralized state control system, and its mutual economic relations have improved. China has grown to be India's topmost trading partner with $\$ 80$ billion bilateral trade (2017-2018). Despite having the sturdy economic ties, however, the tension has not deescalated as expected. For India, the project CPEC is a looming menace and India takes it either as propaganda to fail the economy of other regional countries or to authorise Pakistan by China (Tikhonova, 2017).

After Pakistan refused India to trade with Afghanistan through Pakistan (Sachdeva, 2018) making Indian access to Afghanistan and Central Asia complicated. However still, if India recognizes its benefits from the CPEC project, it can generate many pathways to resolve the disputes. India needs to be aware of the plethora of ways; she can benefit herself by agreeing to be a part of this project. The foremost will be the access of India to central Asian 
Republicans. Over the past several centuries, central Asia and India both have fostered vast trade and commerce association. For this reason, their mutual relation is historical in nature. From the third century BC to $15^{\text {th }}$ century AD, Silk route linked India with Central Asia as soon as the marine course from Europe to India was exposed. Religion is another main cause behind this intrinsic alliance. Since Buddhism has its roots in India and from here, it made its way into Central Asia, and a score of Central Asian sovereigns ruled in India, therefore, religion played a pivotal role in bringing the people closer. For India, the Central Asia region has always been highly significant on account of many other reasons. Central Asia indubitably is of gigantic worth for an emerging market like India since the Central Asian region is blessed with abundant natural resources of natural gas, crude oil, uranium, copper, aluminium, iron and gold; consequently garnering desirability for foreign incursions and internal and external regional power broils (Hafeez, 2007; see, Ali, Ali, \& Ullah, 2018).

India's addition in CPEC can stimulate local progress, business, and economic connectivity a step further by granting India access to a colossal market in central Asia. This will also allow the other countries to be able to sell their commodities in South Asian regions. Pakistan has not allowed India to trade with Afghanistan through Pakistan as foreign office declared by quoting Shah Mahmood Qureshi (foreign minister) that Pakistan is not agreed for the India Afghanistan trade through their territory (Hindustan Times, 2018). With the inclusion of India in CPEC, Pakistan will also allow India for the trade route and India can use Pakistan's territory for the trade with Afghanistan. Other than offering new economic opportunities to Pakistan, new doors to have North-South regional trade connectivity can be opened for India, Pakistan, Afghanistan, and the Central Asian States through CPEC.

It may be useful to carefully evaluate those components of the BRI, which will improve India's connectivity to major markets and resource supplies. Inclusion of India will boost its economy and heighten the speedy industrialisation and employment rate. If India happens to stay aloof from One belt One Road (OBOR), she will only augment its remoteness within South Asia. The sole solution to avoid any regret later is to join OBOR and invite Chinese investment in Indian infrastructure. This collaboration will result in amplifying trade and economic ventures with other south Asian countries also and of course, with China and as a pour out effect with Pakistan too (Jha, 2016). By isolation, India might risk herself being thoroughly stationary and out of business prospects in an expanded region that is integrating with the Chinese economy worldwide (Joshi, 2017).

Bangladesh, China, India, Myanmar (BCIM) Economic Corridor is also a part of OBOR where there is India in the project as well. India can take benefit from CPEC by linking it with the BCIM project. In fact, one of the most significant platforms between China and India is BCIM where both the states are working together to strengthen the underdeveloped places (Karim, \& Islam, 2018). Apart from the BCIM, there is an Asian Infrastructure Investment Bank (AIIB), where India is one of the main founding members of this initiative with the $2^{\text {nd }}$ prime significant shareholder of the bank. In Mumbai, they have also hosted the meeting of chief negotiators for the bank. India has also started cooperation on the bricks bank with China, this initiative is started to It is also cooperating with China on Bricks Bank which is supposed to sponsor the needs of infrastructure in the developing world. It shows that India does have a cooperative and positive stance towards belt and road initiative (Singh, 2016). Therefore, India must realize the importance of CPEC as well, which is another important project of OBOR, that can improve China-India relations and eventually will have a spill over the effects on Pakistan-India relations too. 


\subsection{The Need for Peace Journalism}

Johan Galtung, father of peace studies defined two types of journalism, named as war journalism and peace journalism. Spread of positive awareness among the people through media is basically peace journalism (Galtung, 1967). Media can use this type of journalism to promote peace and harmony, and it can also help to resolve the conflicts within intra or interstate level. By agenda-setting theory, media can also shape the viewpoints of personals by setting a certain agenda (Syed, 2016). This concept of peace journalism is getting remarkable popularity around the world because of its distinguishing feature of resolving disputes by holding the even-handedness and balance in reporting (Riaz, 2017). In the $21^{\text {st }}$ century, 'information' is one of the most powerful tools for conflict resolution which can manipulate or change the mindset, ideologies, and perception of different. Media, whether it is electronic, print, or social media, is a form of information, and it has the ability to promote peace, stability, and harmony by the correct and responsible use of information. Undoubtedly, mass media can be utilized in both ways positively: like for promotion of peace through the use of media and negatively, like use of mass media for propaganda, which can eventually give the wrong impression to the society as well as to the neighbouring countries. Regional integration is need of the hour for South Asia, and CPEC can be used for economic integration.

In this connection, the role of mass media is particularly very important, like mass media can be utilized for giving positive message to the people about this project for instance the positive outcomes of the project in all dimensions e.g. economy, infrastructure, technology etc. In addition, the role played by the Indian media in this regard is very unfortunate because they are biased towards this project. India is now surrounded by BRI projects and through these; China is trying to 'leverage regional security and stability in South Asia.' Since India is deprived of a counter strategy, so all she has come down to is initiate harmful activities to slander the BRI and for which there are no buyer of this malign propaganda internationally' (Sachdeva, 2018). The Indian mainstream newspapers and TV news channels are telling their audience the Pakistani government's strategies for the CPEC in their own perception (biased) rather than telling them the facts and positive outcomes of this project (Adnan, 2018). The ratio of negative coverage in the period of 2016 to 2017 when it was the hot and debatable topic, is more as compared to the positive coverage of CPEC project and Pak-China friendship. Pakistan and China relations are a result of an agreement to defy the Indian hegemony in South Asia as CPEC route is in the proximity to Kashmir valley, and this venture has measured an infringement of the Indian integrity about its terrain. China and Pakistan share several strategic interests against India, which could manipulate the peace in Southeast Asia if the project is accomplished lucratively (Adnan, 2018).

\section{Conclusion}

Keeping in view the complex interdependence theory, India and Pakistan can alleviate the stress that by the CPEC project when both the states will be in the same platform. No doubt the Indian economy is stronger than Pakistan, and with the inclusion of India in this project, geopolitical and economy of India will boost more. Both the states will economically depend on one another on account of their own advantages and national interests. Not only interdependence, the complex interdependence theory significantly pays attention to the 'interaction' between the states. When they start interacting one another, it also helps them to bring them closer so CPEC can be an ideal platform where both the states can interact to get 'information' about each other and which can eventually mitigate the negative peace between 
both the states. However, the addition of India to CPEC can reciprocally prove a favourable development for regional collaboration and promoting reliance that could eventually be inspiring in determining political disagreements between India, China, and Pakistan affably. The lofty speculations between the neighbours, i.e., China and India, can be alleviated by including India to the CPEC. This closeness can bring peace to the region and China, Pakistan and India can embark on a new journey of economic stability and firmness through mutual security of the CPEC (Ali, 2016).

Media also needs to do positive and sensible journalism about CPEC to benefit the whole region. Critics are essential for the positive functioning of a project but pluralistic and way too negative reporting did not impose a positive message; rather, it generates more problems. As a result of the regional integration, there is a need to have a positive and sensible reporting from both sides of the border. CPEC can open doors for regional trade and economic connectivity and assimilation between the region of East, Central and South Asia. However, this calls for a transformation in the current approach of Pakistan and India towards trade and industry relation. The regional economic amalgamation through CPEC can pave a pathway for peace and harmony by putting aside the political discrepancies through economic collaboration. The states of East Asia, Central Asia and South Asia direly require a further regional economic bond to make the $21^{\text {st }}$ century as the Asian century by forgetting the recurrent political disputes for a fresh start. One of the most significant hopes that can be a medium to commence regional trade and economic incorporation and lessen the tension between India and Pakistan is CPEC as a flagship of OBOR.

\section{References}

Adnan, D. M. (2018). China-Pakistan economic corridor and Indian print media: The case study of elite English press. Journal of Political Studies, 25(1), 229-248.

Afridi, M. K., \& Khalid, I. (2016). The politics of interdependence: A case of China Pakistan Economic Corridor. South Asian Studies, 31(2), 659-671.

Ali, A. (2016). China Pakistan Economic Corridor (CPEC): Prospects and challenges for regional integration. International Journal of Social Sciences and Humanities Studies, 7(1), 1-15.

Ali, R., Ali, I, \& Ullah, S. (2018). SCO as a passage to regional security: Future developments and opportunities for Pakistan. Liberal Arts and Social Sciences International Journal (LASSIJ), 3(1), 19-29. https://doi.org/10.47264/idea.lassij/3.1.3

Begum, S. and Ahmed, S. N. (2016). Changing dynamics of Pakistan-India relationship and Kashmir predicament. Journal of the Punjab University Historical Society, 29(2), 197-204.

Galtung, J. (1967). Theories of peace: A synthetic approach to peace thinking. Oslo: International Peace Research Association.

Grant, C. (2010). India's response to China's rise. London: Centre for Eurpeon Reforms.

Hafeez, M. (2017, October 17). Issu Brief on India's connect Cental Asia policy. Retrieved from Institute of Strategice Studies Islamabad (ISSI). http://issi.org.pk/issue-briefon-indias-connect-central-asia-policy/

Hanna, S., Vaughn, L., and Eisenstein, J. (2016, May 03). Interdependence. Retrieved from Jimi Sol. (channel); https://www.youtube.com/watch?v=4FdwZK6pL1M 
Hanif, C. (2018, January 17). China Pakistan Economic Cooridor. Retrieved from China Pakistan Economic Cooridor; http://www.cpecinfo.com/cpec-newsdetail?id=NDcyNQ==

Hindustan Times (2018, September 17). Have not agreed to open Afghan trade route to India, Pakistan clarifies. Retrieved from; https://www.hindustantimes.com/indianews/have-not-agreed-to-open-afghan-trade-route-to-india-pakistan-clarifies/storyNkXuVJV6yXlCCDnmf3YI5J.html

Idrees, M., Naazer, M. A., \& Rehman, A. U. (2017). Conflict and conflict management in SAARC. Liberal Arts and Social Sciences International Journal, 1(2), 1-11.

Islam (2019, March 5). Before and after Pulwama: The Kashmir issue. Retrieved from Humanitarian and Social Research Center (INSAMER): https://insamer.com/en/before-and-after-pulwama-the-kashmir-issue 2042.html

Jha, P. S. (2016, August 13). Why India must Embrace China's One Belt One Road program. Retrieved from The Wire; https://thewire.in/diplomacy/india-must-embrace-chinasone-belt-one-road-plan

Joshi, M. (2017, May 17). India should work with China on OBOR for its own Economic Benefit. Retrieved from Hindustan Times. https://www.hindustantimes.com/analysis/india-should-work-with-china-on-oborfor-it-s-own-economic-benefit/story-Ebx7FoM65zB1F8sOyGKg4O.html

Karim, M. A. and Islam, F. (2018). Bangladesh-China-India-Myanmar (BCIM) Economic Corridor: Challenges and Prospects. The Korean Journal of Defense Analysis, 30(2), 283-302.

Khatoon, A., Rahim, N. \& Ali, B. (2018). A historical perspective of China's peaceful policies and its rise as world economic power. Liberal Arts and Social Sciences International Journal (LASSIJ), 2(1), 65-74.

Keohane, R. O., \& Nye, J. S. (1987). Power and Interdependence Revisited. International Organization, 41(4), 725-753.

Malik, S. A. (2017). China-Pakistan Economic Corridor: Impact on regional stability of South Asia. International Journal of Political Science and Development, 5(6), 192-202.

Masood, Y. (2018, August 08). Why India fear and oppose CPEC? Retrieved from Times of Islamabad; https://timesofislamabad.com/08-Aug-2018/why-india-fear-and-oppose$\underline{\mathrm{cpec}}$

Mohan, C. R. (2018, August 14). Raja Mandala: Breaking the Radcliffe barrier. Retrieved from The Indian Express; https://indianexpress.com/article/opinion/columns/indiapakistan-china-relation-imran-khan-xi-jinping-narendra-modi-china-belt-and-roadinitiative-5305200/

Rana, W. (2015). Theory of complex interdependence: A comparative analysis of realist and Neoliberal thoughts. International Journal of Business and Social Science, 6(2), 290297.

Ranjan, A. (2015). The China-Pakistan Economic Cooridor: India's Option. Institute of Chinese Studies, 10(1), 1-25.

Rehman, A. U., Hakim, A., Khan, K., \& Khan, I. U. (2018). Role of CPEC in development of trade, transport, and economy of Pakistan. Romanian Journal of Transport Infrastructure 7(1), 77-92.

Rehman, A. U., Ashfaq, S., \& Khan, T. M. (2018). Kargil operation and its effects on civilmilitary relations in Pakistan. Liberal Arts and Social Sciences International Journal 2(2), 10-21.

Riaz, S. (2017). Role of media in promoting peace and harmony. ISSRA Papers, 9(2), 99-114. 
Sachdeva, G. (2018). Indian perceptions of the Chinese Belt and Road Initiative. International Studies, 55(4), 285-296.

Singh, G. S. (2016). India and China: Constructing a peaceful order in the Indo-Pacific. New Delhi: National Maritime Foundation.

Syed, A. (2016, June 28). Role of media in promoting Indo-Pak peace: A Case study of "Aman ki Asha" initiative. Retrieved from Foreign Policy News. http://foreignpolicynews.org/2016/06/28/role-media-promoting-indo-pak-peacecase-study-aman-ki-asha-initiative/

Tikhonova, P. (2017, January 20). Do Pakistan and China really need India in CPEC? Retrieved from Value Walk (VW); https://www.valuewalk.com/2017/01/do-pakistan-chinaneed-india-cpec/

Walker, T. C. (2013). A circumspect revival of liberalism: Robert O. Keohane and Joseph S. Nye's Power and Interdependence. In Classics of International Relations (pp. 160186), Rutledge. 